\title{
Genetic Relationships among Cultivars and Landraces of Lima Bean (Phaseolus lunatus L.) as Measured by RAPD Markers
}

\author{
James Nienhuis ${ }^{1}$ Jan Tivang ${ }^{2}$, and Paul Skroch ${ }^{2}$ \\ Department of Horticulture, Univesity of Wisconsin, Madison, WI 53706 \\ Joao B. dos Santos ${ }^{3}$ \\ Escola Saperior de Agricultra de Lavras, Lavras, MG, Brazil

\begin{abstract}
Additional index words. moleular markers, random amplified polymorphic DNA, genetic distance, Multidimensional scaling, sampling variance, genetic diversity
\end{abstract}

\begin{abstract}
Knowledge of relative genetic distance among genotypes is useful in a breeding program because it permits organization of germplasm resources. Genetic distance (GD) was estimated among 65 Phaselous lunatus L.. accessions, which included 4 large-seeded and 7 small-seeded cultivars and 54 germplasm accessions (landrace's) from the Caribbean and North, Central, and South America. Based on 125 polymorphic random amplification polymorphic DNA (RAPD) bands, two major clusters, which generally correspond in seed size and geographic region to [be Mesoamerican and Andean gene pools, were observed among the landraces (GD $=0.726 \pm 0.041)$. Four Fordhook cultivars and a landrace from the United States formed a separate cluster that is more distantly related to the small- $($ GD $)=0.561 \pm 0.039)$ than to the large-seeded cluster $(G D=0.303 \pm \mathbf{0 . 0 2 2}$ ). The mean GD between the Andean and Mesoamerican (0.726), Mesoamerican and Fordhook (0.561), and Andean and Fordhook (0.303) clusters were all significant. The significant GD between the Andean and Mesoamerican groups supports the hypothesized existence of two major gene pools in lima bean. The RAPD marker diversity of the Mesoamerican group was the largest (0.1 10), followed by the Andean (0.097) and Ford hook (0.062) groups. The plot of the relationship between the coefficient of variation (cv) and sample size (number of bands) indicates that cvs as low as $\mathbf{1 0 \%}$ for estimating CD between Andean and Mesoamerican lima bean accessions can be achieved by sampling as few as 100 bands.
\end{abstract}

Cultivars and landraces of a crop species represent the primary gene pool available to plant breeders for hybridization and inprovement of crop plants (Harlan and De Wet, 1971). Knowledge of the genetic relationships among cultivars and between cultivars and landraces is useful to the plant breeder because it permits organization of germplasm resources and allows for more efficient sampling of available genetic diversity.

Patterns of genetic diversity have been studied in crop species using a variety of molecular, chemical, and morphological descriptors. The most commonly used molecular tools for measuring genetic relationships have been isozymes, seed proteins, and molecular markers. Although informative and practical. the use of' variable protein and isozyme markers has often been limited by their low frequency in many crop species (Goodman and Stuber, 1980). Molecular markers provide an opportunity to measure genetic relationships more precisely than morphological and biochemical markers because they 1) are potentially unlimited in number, 2) are not affected by the environment, and 3) can be organized into linkage maps (Soiler and Beckmann. 1983; Helentjaris et al., 1986). Estimates of genetic relationships based on restriction fragment length polymorphisms (RFLPs) have been shown to be consistent with expectations based on known breeding behavior and pedigrees in numerous crop species, including maize (Dudley, 1994; Smith et al., 1990). More recently, scientists have used random amplified polymorphic DNA (RAPD) molecular markers as a tool for measuring genetic relationships (Skroch et al.,

Received for publication 26 May 1994. Accepted for publication 4 Oct. 1994. The cost of publishing this paper was defrayed in part by the payment of page charges. Under postal regulations, this paper therefore must be hereby marked advertisement ment soley to indicate this fact.

'Assistant professor.

${ }^{2}$ Graduate research assistant.

${ }^{3}$ Professor
1992; Welsh and McClelland, 1990, Williams et a1., 1990). RAPDs are technically simpler and cost less than RFLPs; however, reproducibility of banding patterns can be affected by different concentrations of reaction components and cycling conditions (Weeden et al., 1992). Nevertheless, in a study comparing molecular markers, the sampling variances associated with RAPDs and RFLPs were found to be similar for estimation of genetic relationships among Brassica oleracea genotypes (dos Santos et al., 1994).

Based primarily on the size, shape, and color of seeds, lima bean diversity was originally organized into three main gene pools: 1 ) the Hopi blanch, extending northward from Central America into the United States; 2) the Carib branch, including the islands in the West Indies and Amazon basin of Brazil; and 3) the Inca branch. extending southward from Central America to Peru (Mackie, 1943). More recent evidence, based on patterns of isozyme variation, indicates the existence of only two gene pools in lima beans, Mesoamerican and Andean (Baudoin, 1988; Debouck et al., 1989). The Meso american lima bean gene pool extends from the southwestern, United States to Argentina and is characterized by small seed size ( 0.24 to $0.70 \mathrm{~g} / \mathrm{seed})$ (Debouck et al., 1989: Maquet et al., 1990). The Andean lima bean gene pool extends from the equator to north of Peru for wild forms and from Colombia to southern Brazil for cultivated forms and is characterized by large seed size (>0.54 g/seed) (Debouck et al., 1989; Maquet et al., 1990; Maquet et al., 1993).

Lima bean cultivars harvested at the immature seed stage for processing as a vegetable are generally classified into two groups: Henderson (baby lima) and Fordhook. Henderson types correspond to the Mesoamerican gene pool and are characterized by broad environmental adaptation and small seed size $(<0.50 \mathrm{~g} /$ seed). The original Henderson cultivar was apparently identified in 1883 in Virginia as a chance bush (determinate) plant in a landrace of lima beans cultivated by the Hopi Indians (Holland et al., 1953; 
Mackie, 1943). The Fordhook types correspond to the Andean gene pool and are characterized by narrow environmental adaptation and large seed size $(>.50 \mathrm{~g} / \mathrm{seed})$, Fordhook bush cultivars were derived from landraces that were adapted to the long, cool, dry summers in the Ica region on the coast south of Lima, Peru (Mackie, 1943). The objective of this research was to determine if RAPD molecular markers could be used to 1) estimate the genetic relationships among modern lima bean cultivars derived from the Fordhook and Henderson types and a random sample of accessions (landraces) from germplasm collections and 2) estimate the relative magnitudes of' genetic diversity (RAPD marker variance) among groups of accessions.

\section{Materials and Methods}

Germplasm. Sixty-five lima bean genotypes were used in this study (Table 1). Lima bean cultivars included four large-seeded $(\geq 0.63 \mathrm{~g} / \mathrm{seed})$ Fordhook types and seven small-seeded $(\leq 0.44 \mathrm{~g} /$ seed) Henderson (baby lima) types Fifty-four random lima bean accessions (landraces), which represented a broad range of lima bean diversity, were included in this study. Twenty-seven of the accessions were obtained from Steve Beebe, Genetic Resources Unit, C. I. A. T., Cali, Colombia (G preceding accession number) and the remaining twenty-seven accessions from Richard Hannan, U.S. Dept. of Agriculture-Agricultural research Service, Plant Introduction Station, Pullman. Wash. (PI preceding accession number).

Phenotypic characterization. Mean seed weight was calculated from a sample of 10 seeds from each entry (Table 1). Seed width was measured as the longest distance on the flattest surface of the seed bisecting the hylum, seed height was the longest distance between the two flattest surfaces of the seed, and seed length was measured as the longest distance on the flattest surface of the seed parallel to the hylum. The mean width, height, and length of a 10seed sample were calculated for each entry. Five seeds of each entry were planted in June 1992 in unreplicated, 1-m-long plots at the Hancock (Wis.) Experiment Station, Hancock. using standard cultural practices. Each accession and cultivar was subjectively classified for flowering as follows: $1=$ flowered and produced many seeds, 2 = flowered and produced few seeds, $3=$ flowered but did not produce seeds, $4=$ flowered late in season and, $5=$ did not flower.

$R A P D$ procedures. A sample of 10 seeds of each entry was germinated in a greenhouse, and $2 \mathrm{~g}$ of immature unifoliate leaves was used for extracting DNA, The fresh leaves were ground in 10 $\mathrm{ml}$ of extraction buffer at $65 \mathrm{C}$ using a mortar and pestle. The extraction buffer contained 2\% CTAB, 100 mM tris (pH 8.0). 20 mu EDTA (pH 8.0). $1.4 \mathrm{M} \mathrm{NaCl}$, and 1\% PVP (polyvinylpyrolidone) (Rogers and Bendich, 1988). After grinding, the tissue was transferred to centrifuge tubes and allowed to soak for $30 \mathrm{~min}$ in a hot water bath at $65 \mathrm{C}$. Following this soak, the mixture was extracted once with an equal volume of 24 chloroform : 1 isoamyl alcohol.

After organic and aqueous phases were separated by centrifugation, nucleic acids were precipitated by pipetting the aqueous phase into at least three volumes of a 6:1 mixture of 95\% ethanol and ammonium acetate, Precipitating nucleic acids were allowed to stand overnight at $-20 \mathrm{C}$. Nucleic acids were transferred with a wide bore pipette into $1.5-\mathrm{ml}$ microcentrifugc tubes. After spire ning for 15 to $30 \mathrm{sec}$ at $14,000 \mathrm{rpm}$ in a microcentrifuge, pellets were rinsed with a $70 \%$ ethanol solution and repelleted. The pellet was rehydrated in a dilute TE buffer ( $1 \mathrm{~mm}$ tris and $0.1 \mathrm{~mm}$ EDTA). RNA was removed by treatment with RNase A at $100 \mu \mathrm{g} \cdot \mathrm{ml}^{-1}$ for $1 \mathrm{~h}$ at $37 \mathrm{C}$. Samples were then spun and transferred to clean microcentrifuge tubes. DNA was precipitated by the addition of at least two volumes of a 20:1 mixture of $95 \%$ ethanol and sodium acetate. After precipitation and pelleting, DNA was rehydrated in a TE buffer and quantified using a Hoefer Scientific TKO 100 fluorometer.

RAPD reactions were mixed in volumes of $10 \mu \mathrm{l}$ using the following reagents: $20 \mathrm{ng}$ of genomic template, $100 \mu \mathrm{M}$ of dNTP, $0.4 \mu \mathrm{M}$ of primer, 0.6 units of Taq polymerase (Promega, Madison, Wis.), $2.0 \mathrm{~mm}$ of $\mathrm{MgCl}_{2}, 50 \mathrm{~mm}$ tris $\mathrm{pH} 8.5,2 \mathrm{mM} \mathrm{MgCl}_{2}, 20 \mathrm{~mm}$ $\mathrm{KCl}, 5 \mu \mathrm{g} \cdot \mu^{-1} \mathrm{BSA}, 2.5 \%$ of Ficoll 400 , and $0.002 \%$ xylene cyanole. The reactions were performed in glass capillary tubes in a thermal cycler (Idaho Technology, Idaho Falls, Idaho). The thermal cycler was programmed to cycle 40 times under the following conditions: for the first two cycles, denaturation for 60 $\mathrm{sec}$ at $91 \mathrm{C}$, annealing for $7 \mathrm{sec}$ at $42 \mathrm{C}$, and elongation for $70 \mathrm{sec}$ at $72 \mathrm{C}$; the subsequent 38 cycles were run with the denaturation time reduced to $1 \mathrm{sec}$ at $91 \mathrm{C}$. After amplification, the reaction products were separated by electrophesis in $1.5 \%$ agarose gels, stained with ethidium bromide, and photographed under ultraviolet light with Polaroid 667 film.

The number of polymorphic primers used from sets A, B, C, D, E, F, and L (Operon Technologies, Alameda, Calif. ) were 3,5, 5, $6,4,1$, and 1 , respectively. Information on specific primers is available from the authors. Polymorphic bands were classified as intense, medium, or faint, based on resolution and degree of' amplification (Weeden et al., 1992). Only bands classified as intense or medium were included in the analysis. From 2 to 8 bands, which were polymorphic among the genotypes included in this study, were scored for each of the 25 primers resulting in a total of 125 scored bands.

Genetic distance estimates and MDS plots. Each polymorphic RAPD band across all accessions was assigned a number (1, 2, 3 ...n) according to decreasing molecular weights. Each band was treated as a unit character, and the accession was scored for the presence or absence of a band and coded as 1 or 0 , respectively. Genetic distances were calculated between all 2080 pairs of accessions based on the following formula, which is the complement to the simple matching coefficient (Gower, 1985):

$$
G D(i, j)=S^{N}(i \neq j) /\left[S^{N}(i \neq j)+S^{N}(i \neq j)\right]
$$

where $\operatorname{GD}(i, j)$ is the measure of genetic distance between accessions $i$ and $j, S^{\mathrm{N}}(i \neq j)$, and $S^{\mathrm{N}}(i \neq j)$ are the total number of discordant and concordant scores between accessions $\mathrm{i}$ and $\mathrm{j}$, respectively. GD values of 0.0 and 1.0 indicate no and maximum difference between two accessions, respectively.

The $65 \times 65$ triangular matrix of GD values is too lengthy to be presented here, but is available upon request from J. Nienhuis. The $65 \times 65$ matrix of GD estimates was reduced to two dimensions and displayed as a multidimensional scaling (MDS) plot (Wilkinson, 1989). Based on the MDS plot, the accessions were classified into two groups, Mesoamerican and Andean, which generally corresponded with seed size and geographic origin. The Andean group included 25 entries, excluding the Fordhook-type cultivars; the Mesoamerican group included the seven Henderson-type cultivars and 28 accessions. Separate MDS analyses were performed on the GD matrices corresponding to the Andean and Mesoamerican groups.

Mean CD was calculated between the three groups observed in the MDS plot: Mesoamerican, Andean, and Fordhook types. An F test modified from the analysis of molecular variance (AMOVA) was used to test the significance of differences between the groups of accessions (Excoffier et al., 1992). The relevant F value to test the significance of differences between groups of accessions was 
Table 1. Lima bean cultivars and accession included in genetic distance study.

\begin{tabular}{|c|c|c|c|c|c|c|c|c|}
\hline \multirow[b]{2}{*}{$\begin{array}{l}\text { Entry } \\
\text { no. }\end{array}$} & \multirow[b]{2}{*}{$\begin{array}{l}\text { Name or } \\
\text { accession }\end{array}$} & \multirow[b]{2}{*}{ Origin } & \multicolumn{5}{|c|}{ Seed $^{x}$} & \multirow[b]{2}{*}{$\begin{array}{l}\text { Flowering" } \\
\text { classification }\end{array}$} \\
\hline & & & Color $^{y}$ & $\begin{array}{l}W \mathrm{t} \\
(\mathrm{g}) \\
\end{array}$ & $\begin{array}{l}\text { Width } \\
(\mathrm{mm})\end{array}$ & $\begin{array}{c}\mathrm{H} \mathrm{t} \\
(\mathrm{mm})\end{array}$ & $\begin{array}{c}\text { Length } \\
(\mathbf{m m})\end{array}$ & \\
\hline \multicolumn{9}{|c|}{ Cultivar } \\
\hline 1 & Burpec Improved & U.S. & White & 1.19 & 16.3 & 1.3 .4 & 20.3 & 1 \\
\hline 2 & Fordliouk 242 & U.S. & Whitc & 1.14 & 8.0 & 12.6 & 16.2 & 1 \\
\hline 3 & King of Garden & U.S. & White & 1.00 & 5.9 & 12.0 & 21.0 & 1 \\
\hline 4 & Fordhook 169 & U.S. & Green & 0.63 & 6.0 & 10.4 & 14.9 & 1 \\
\hline 5 & Maffei 15 & U.S. & White & 0.44 & 5.3 & 10.8 & 14.4 & 1 \\
\hline 6 & Jackson Wonder & U.S. & Brown/light & 0.40 & 4.4 & 9.9 & 15.0 & 1 \\
\hline 7 & Early Thorogreen & U.S. & Green & 0.39 & 4.6 & 10.4 & 13.4 & 1 \\
\hline 8 & New Kingston & U.S. & White & 0.38 & 6.2 & 9.9 & 11.1 & 1 \\
\hline 9 & Packer & U.S. & White & 0.36 & 4.8 & 9.2 & 12.6 & 1 \\
\hline 10 & EastLand & U.S. & Green & 0.33 & 4.3 & 10.4 & 12.5 & 1 \\
\hline 11 & PSBG1-bridgeton & U.S. & Green & 0.29 & 5.0 & 9.0 & 11.2 & 1 \\
\hline \multicolumn{9}{|c|}{ Germplasm bank accessions (landraces) } \\
\hline 12 & PI306196 & Рeru & White & 2.06 & 6.0 & 18.0 & 28.0 & 4 \\
\hline 13 & PI241791 & Peru & White & 1.50 & 7.3 & 16.3 & 25.4 & 3 \\
\hline 14 & PI256872 & Peru & White & 1.43 & 5.8 & 14.2 & 23.3 & 5 \\
\hline 15 & PI256883 & Peru & White & 1.41 & 4.6 & 14.4 & 21.8 & 4 \\
\hline 16 & PI306197 & Peru & White & 1.39 & 5.8 & 15.2 & 25.1 & 4 \\
\hline 17 & PI241784 & Peru & Brown/lark & 1.38 & 6.2 & 14.7 & 24.5 & 5 \\
\hline 18 & PI358288 & Ethiopia & White/red dots & 1.32 & 6.8 & 1.3 .3 & 23.3 & 5 \\
\hline 19 & PI256904 & Peru & White & 1.26 & 5.0 & 14.4 & 24.0 & 5 \\
\hline 20 & PI256909 & Peru & White/red dots & 1.24 & 5.9 & 14.5 & 23.3 & 4 \\
\hline 21 & G25300 (Pallar) & Peru & White & 1.22 & 6.2 & 13.6 & 25.5 & --- \\
\hline 22 & G25981 (Pallar or Chuies) & Boliva & Grey & 1.20 & 5.5 & 14.7 & 24.8 & --- \\
\hline 23 & PI256881 & Peru & White & 1.17 & 6.2 & 14.9 & 24.0 & 4 \\
\hline 24 & G25985 & Boliva & Black/white dots & 1.11 & 4.3 & 14.2 & 23.1 & 5 \\
\hline 25 & G25980 & Boliva & White/brown dots & 1.08 & 4.7 & 13.7 & 24.0 & 5 \\
\hline 26 & G25989 & Boliva & Red/white dots & 1.05 & 4.4 & 15.2 & 25.0 & 5 \\
\hline 27 & Pl257393 & Colombia & White & 1.05 & 5.4 & 13.4 & 23.3 & 5 \\
\hline 28 & G25517 & Colombia & Gray/red & 1.04 & 9.0 & 13.0 & 16.5 & 4 \\
\hline 29 & $\mathrm{PI} 256870$ & Peru & White & 1.04 & 6.8 & 13.8 & 17.9 & 3 \\
\hline 30 & $G 25267$ & El Salvador & Whire & 0.99 & 4.9 & 12.4 & 20.3 & 1 \\
\hline 31 & $G 25579$ & Boliva & Black/white dots & 0.98 & 4.8 & 14.9 & 24.2 & 5 \\
\hline 32 & PI256913 & Регu & Gray & 0.78 & 7.0 & 11.8 & 16.2 & 3 \\
\hline 33 & PI477041 & U.S. & Brown & 0.78 & 5.0 & 11.9 & 19.3 & 3 \\
\hline 34 & PI256846 & Peru & White & 0.77 & 6.4 & 12.2 & 16.5 & 3 \\
\hline 35 & PI256845 & Peru & White & 0.75 & 7.2 & 13.4 & 14.9 & 3 \\
\hline 36 & PI257416 & Argentina & Gray & 0.73 & 4.5 & 12.4 & 17.6 & 3 \\
\hline 37 & G25821 & Colombia & Gray/purple dots & 0.69 & 7.7 & 10.2 & 15.9 & 4 \\
\hline 38 & PI256823 & Peru & Gray & 0.63 & 8.2 & 10.8 & 11.3 & 3 \\
\hline 39 & PI427216 & U.S. & White & 0.62 & 5.8 & 11.6 & 15.0 & 3 \\
\hline 40 & PI451715 & U.S. & Red & 0.54 & 4.7 & 10.7 & 15.6 & 4 \\
\hline 41 & G25296 & Cuba & Gray & 0.51 & 5.5 & 10.1 & 14.4 & 5 \\
\hline 42 & PI 440808 & U.S. & Brown & 0.43 & 5.3 & 8.9 & 14.1 & 4 \\
\hline 43 & 625547 & Argentina & White & 0.42 & 3.7 & 9.8 & 13.5 & 3 \\
\hline 44 & G25623 & U.S. & White & 0.42 & 4.7 & 9.3 & 13.3 & 2 \\
\hline 4.5 & G25626 & U.S. & White & 0.42 & 5.3 & 9.7 & 12.1 & 3 \\
\hline 46 & G25176 (Jackson Wonder) & U.S. & Brown/purple dots & 0.41 & 1.0 & 9.5 & 14.5 & 1 \\
\hline 47 & G26222 & Caribe & White & 0.40 & 4.9 & 9.7 & 15.1 & 2 \\
\hline 48 & PI257375 & Colombia & White & 0.40 & 4.7 & 9.6 & 12.5 & 2 \\
\hline 49 & G25137 (Jackson Wonder) & U.S. & Brown/purple dots & 0.40 & 4.1 & 9.2 & 13.8 & 1 \\
\hline 50 & G25545 & Argentina & White & 0.39 & 4.6 & 10.0 & 13.9 & 4 \\
\hline 51 & G25107 & Brazil & White & 0.39 & 4.4 & 8.7 & 13.7 & 3 \\
\hline 52 & G26085 & Brazil & Purple & 0.39 & 6.2 & 8.0 & 10.0 & 4 \\
\hline 53 & G25193 & Mexico & White & 0.38 & 5.1 & 10.0 & 13.0 & 2 \\
\hline 54 & G25515 & Colombia & White & 0.38 & 4.7 & 9.6 & 13.3 & 3 \\
\hline 55 & PI257355 & Colombia & White & 0.36 & 5.4 & 9.8 & 12.2 & 3 \\
\hline 56 & P11981092 & $\ldots$ & White & 0.36 & 5.1 & 10.0 & 11.5 & 3 \\
\hline 57 & G25138 (Allgreen) & U.S. & Whitc & 0.35 & 4.6 & 8.6 & 12.1 & 2 \\
\hline 58 & Pl 451782 & U.S. & Brown/black dots & 0.35 & 4.6 & 10.8 & 14.7 & 3 \\
\hline 59 & G25667 & U.S. & Brown/purple dots & 0.35 & 4.3 & 9.6 & 1.5 .3 & 2 \\
\hline 60 & G25521 & Colombia & White & 0.34 & 4.4 & 9.0 & 13.0 & 3 \\
\hline 61 & G25629 (Hopi 156) & U.S. & White & 0.33 & 3.9 & 8.9 & 11.2 & 3 \\
\hline 62 & P143360)4 & U.S. & White & 0.32 & 4.5 & 8.90 & 11.7 & 1 \\
\hline 63 & $\mathrm{G} 25624$ & U.S. & White & 0.31 & 4.4 & 9.00 & 13.6 & 3 \\
\hline 64 & G25556 & Mexico & Brown/light & 0.28 & 5.1 & 8.40 & 12.3 & 5 \\
\hline 65 & PI502185 & -- & Red & 0.27 & 3.9 & 9.10 & 12.5 & 3 \\
\hline
\end{tabular}

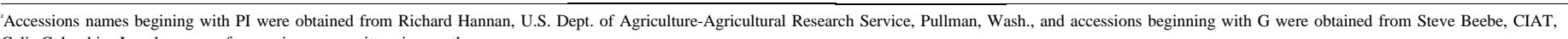
Cali, Colombia. Local names of accessions are written in paretheses.

'The first color indicated is the solid or background color, the second is mottled over the first.

"Mean of 10 seeds.

"Classification scale 1 = produced many seeds, 2 = produced few seeds, 3 = produced no seeds, but flowered, 4 = produced flowers late in season, $5=$ did not flower when planted in early June 1992 at Hancock, Wis. 
the ratio of the mean square for the interaction between marker frequency and group relative to the interaction between marker frequency and individual accessions nested within each group.

Sampling variance. Bootstrap samples were drawn from the full data set and from subsets corresponding to the Andean and Mesoamerican groups. One hundred bootstrap samples each of size $\mathrm{n}(\mathrm{n}=10,20,30 \ldots \mathrm{n})$ were drawn independently from each data set (Tivang et al., 1994). The GD between all pairs of accessions was calculated for each bootstrap sample. The variance among the 100 bootstrap samples for each pair of accessions was standardized to the coefficient of variance (CV) by dividing the variance by the bootstrap sample mean.

Genetic diversity. Genetic diversity (RAPD marker diversity) was estimated within each of the three groups (Andean, Mesoamerican, and Fordhook) as Nei's gene diversity at a locus, $\left.\mathrm{h}=\left(1-\sim \mathrm{x}_{\mathrm{i}}^{2}\right) \mathrm{n} / \mathrm{n}-1\right)=2 \mathrm{pqn} /(\mathrm{n}-1)$, where $\mathrm{p}$ is the frequency of absence of RAPD amplification at a locus and $n$ is the number of individuals evaluated, averaged over all 125 loci (Nei, 1987). Comparison of populations was done using t tests. Standard errors fort tests were computed using the bootstrap (Efron and Tibshirani, 1987).

\section{Results and Discussion}

Relationships revealed by the MDS plots. Inspection of the MDS plot indicated three distinct clusters of accessions with no overlap (Fig. 1). The accessions within the two main clusters generally corresponded in seed size and geographic region to the Mesoamerican and Andean gene pools described by Debouck
(1989) (Table 1). Within the large-seeded accessions, the Fordhook cultivars formed a third distinct cluster. The mean GD between the Andean and Mesoamerican (0.726), Mesoamerican and Fordhook (0.561), and Andean and Fordhook (0.303) clusters were all significant (Table 2). The significant GD between the Andean and Mesoamerican groups supports the proposal by Debouck et al. (1989) of the existence of two major gene pools in lima bean.

Entry 30 has large, white seeds, a determinate (bush) growth habit, and seed shape and flowering characteristics very similar to the Fordhook-type cultivars included in this study (Table 1). Based on its phenotypic characteristics and clustering in close proximity to the Fordhook cultivars, entry 30 likely represents a Fordhook type, which is either feral or cultivated in El Salvador. Thus, the Fordhook cluster includes only cultivars and cannot be considered a third gene pool. The significant distance of the Fordhook cultivars from the other large-seeded, mostly indeterminate growth habit types suggests that the development of Fordhook cultivars was not a simple mutation to a determinate growth habit, but rather involved changes at many loci (Fig. 1 and Table 2).

The MDS plot revealed that two entries, 33 and 39, which had mean seed weights of $0.78 \mathrm{~g}$ and $0.62 \mathrm{~g}$, respectively, clustered with the Mesoamerican group (Fig. 2). Both of these large-seeded accessions had white seed and were collected in the United States. Entry 6 was known to be the cultivar Jackson Wonder. Two accessions, which were collected in the United States and which had similar seed color and size (entries 46 and 49), were described by their collectors as having a local name of 'Jackson Wonder'. These three entries grouped in close proximity in the MDS plot (Fig. 2). All the small-seed Henderson-type culitvars (entries 4

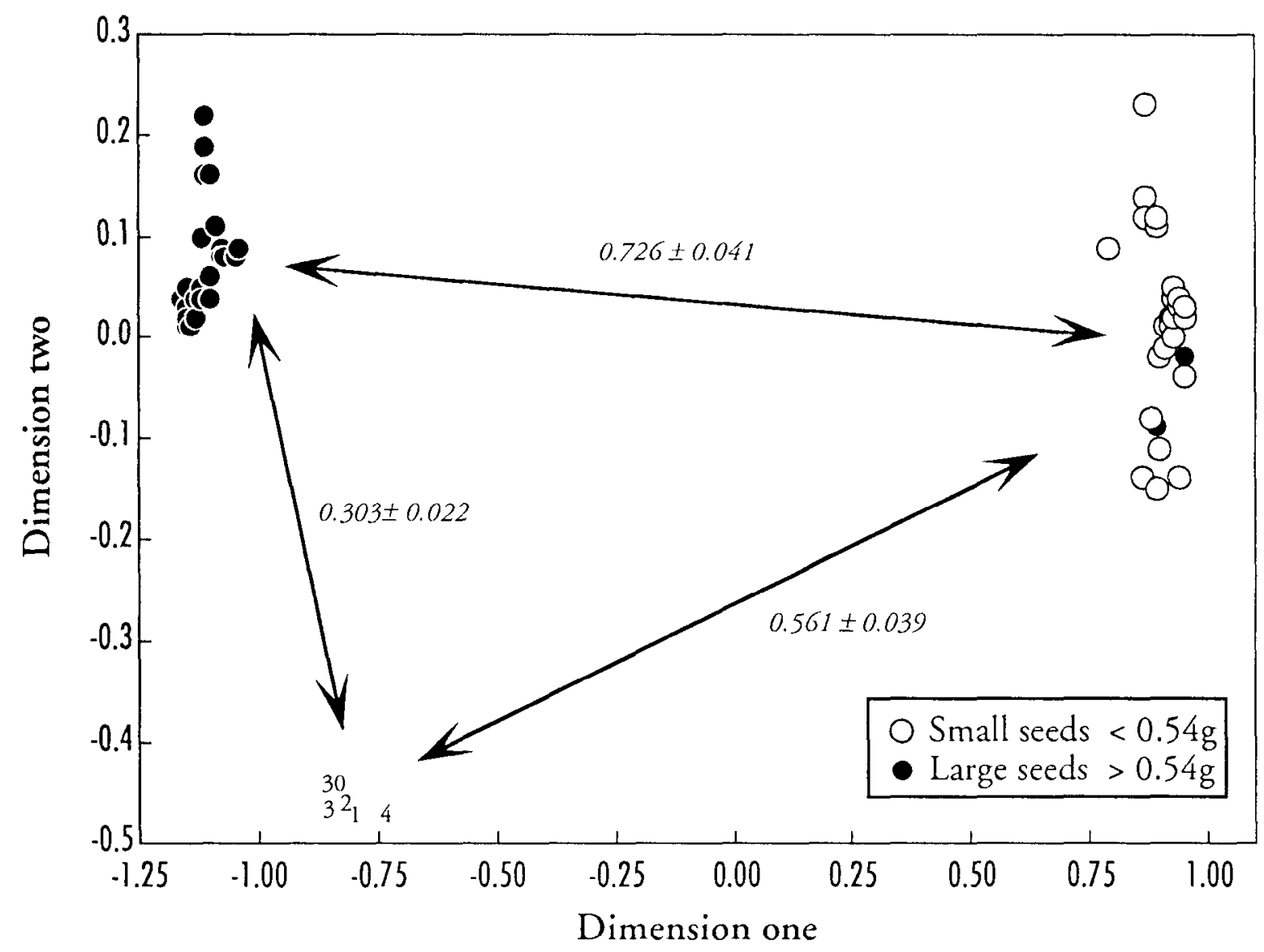

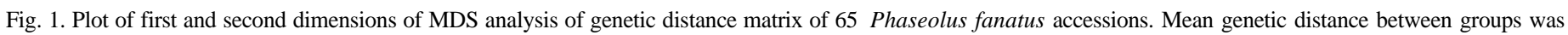
estimated based on 125 polymorphic RAPD bands. Numbered accessions are listed in Table I and represent Fordhook-type cultivars or accessions. 
Table 2. Comparisons of mean genetic distance among Andean, Mesoamerican, and Fordhook groups of Phaseolus lunatus.

\begin{tabular}{lccc}
\hline \hline Comparison & $\begin{array}{c}\text { No. of } \\
\text { comparisons }\end{array}$ & $\begin{array}{c}\text { Mean geneticy } \\
\text { distance }\end{array}$ & $\begin{array}{c}\mathrm{F} \\
\text { value }^{\mathrm{x}}\end{array}$ \\
\hline $\begin{array}{l}\text { Mesoamerican vs. Andean } \\
\text { Mesoamerican vs. Fordhook }\end{array}$ & 175 & 0.726 & $12.13^{* * *}$ \\
Andean vs. Fordhook & 125 & 0.561 & $10.04^{* * *}$ \\
& & 0.303 & $1.71^{* *}$
\end{tabular}

$\overline{{ }^{2}}\left(\mathrm{~m}^{*} \mathrm{n}\right)$ where $\mathrm{m}$ and $\mathrm{n}=$ the number of accessions in each group respectively.

'Calculated as the mean genetic distance between all $\mathrm{m} * \mathrm{n}$ comparisons. ' $F$ values were calculated from [he analysis of molecular variance comparing the mean squares for genotype $\mathrm{x}$ band frequency between populations vs. the mean square for genotypes nested within population $\times$ band frequency.

$* * *, * *$ Significant at $P=0.001$ or 0.01 . respectively. through 11) included in this study tended to cluster in the MDS plot (Fig. 2). 'New Kingston' (entry 8), a cultivar originally developed for adaptation to high temperature conditions in Utah, appears the most distant from the other small-seeded cultivars (Pollard and Hamson, 1970). In contrast, 'Early Thorogreen', 'East land'. and 'Bridgeton' (entries 7, 10, and 11, respectively) appear to form a separate cluster of cultivars related to one another and to entry 56, a white-seeded accession of unknown origin. Three other cultivars, Maffei 15, Jackson Wonder, and Packer (entries 5.6. and 9, respectively), appear to be more closely related to the other smallseeded accessions.

All large-seeded accessions from Bolivia (entries 22, 24, 25, 26, and 31) clustered in close proximity in the MDS plot of Andean accessions (Fig. 2). All remaining large-seeded accessions from Peru and Colombia formed a separate cluster.

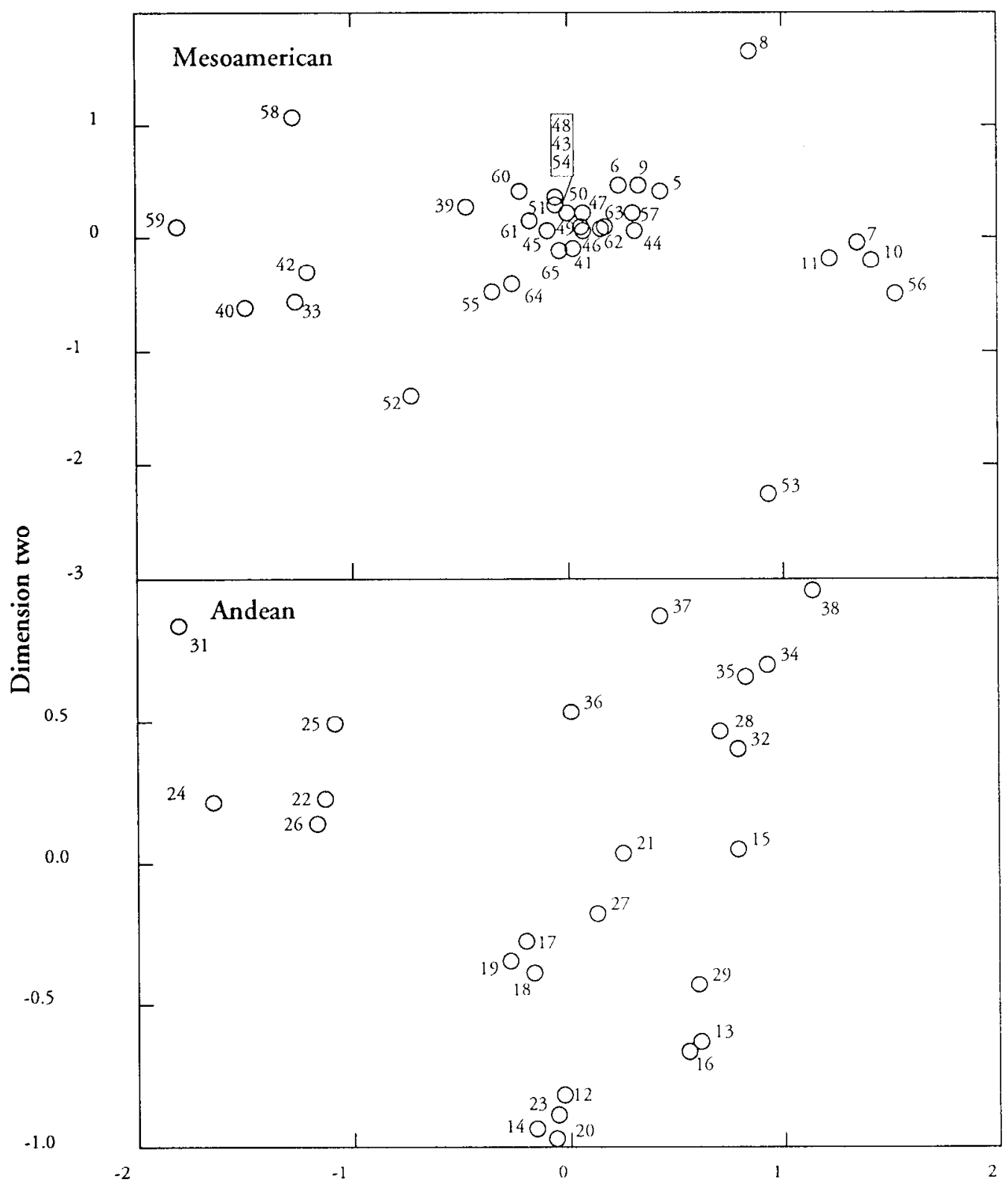

\section{Dimension one}

Fig. 2. Plots of first and second dimensions of MDS analysis of genetic distance matrices of lima bean accessions corresponding to the Mesoamerican and Andean gene pools. Accessions are listed in Table 1. 
Sampling variance. Sampling variance in estimation of genetic relationships occurs when a random subset of marker bands does not equal the value obtained from all possible bands. Larger numbers of random marker bands will provide an increasingly more uniform distribution and will reduce the variance inestimation of genetic relationships clue to over- or undersampling certain regions of the genome (Tivang et al., 1994). The plot of the relationship between the $\mathrm{cv}$ and sample size (number of bands) indicates that cvs as low as $10 \%$ [or estimating CD between Andean and Mesoamerican lima bean accessions can be achieved by sampling as few as 100" bands (Fig. 3). However, fewer bands were polymorphic within the Andean and Mesoamerican gene pools than were polymorphic between them; thus, cvs were larger for comparisons of GD within compared to between gene pools. The cvs for estimating GD within the Andean and Mesoamerican gene pools were $\approx 25 \%$, corresponding to $\approx 40$ and 70 bands, respectively. Although the variance among bootstrap samples was similar within and between the Andean and Mesoamerican gene pools, the cv relationships do not follow the same curve because the mean GD (the divisor used for calculating the cv) was smaller within groups compared to between groups.

Genetic diversity. The basis of genetic diversity is sequence variation. RAPDs are molecular markers that sample and reveal sequence variation by the differential amplification of DNA fragments; thus, genetic diversity within groups of lima bean accessions was measured as RAPD marker diversity. Genetic diversity estimated by RAPD markers was the largest in the Mesoamerican group (0.110) followed by the Andean (0.097) and Fordhook (().()62) groups (Table 3). The Mesoamerican and Andean groups differed significantly from the Fordhook group but were not significantly different from each other.

\section{Conclusions}

Plant breeders can usc RAPD markers to organize genetic resources into related groups to make more informed decisions regarding choice of parents. This capacity is especially useful in this study because the effect of photoperiod on flowering of many

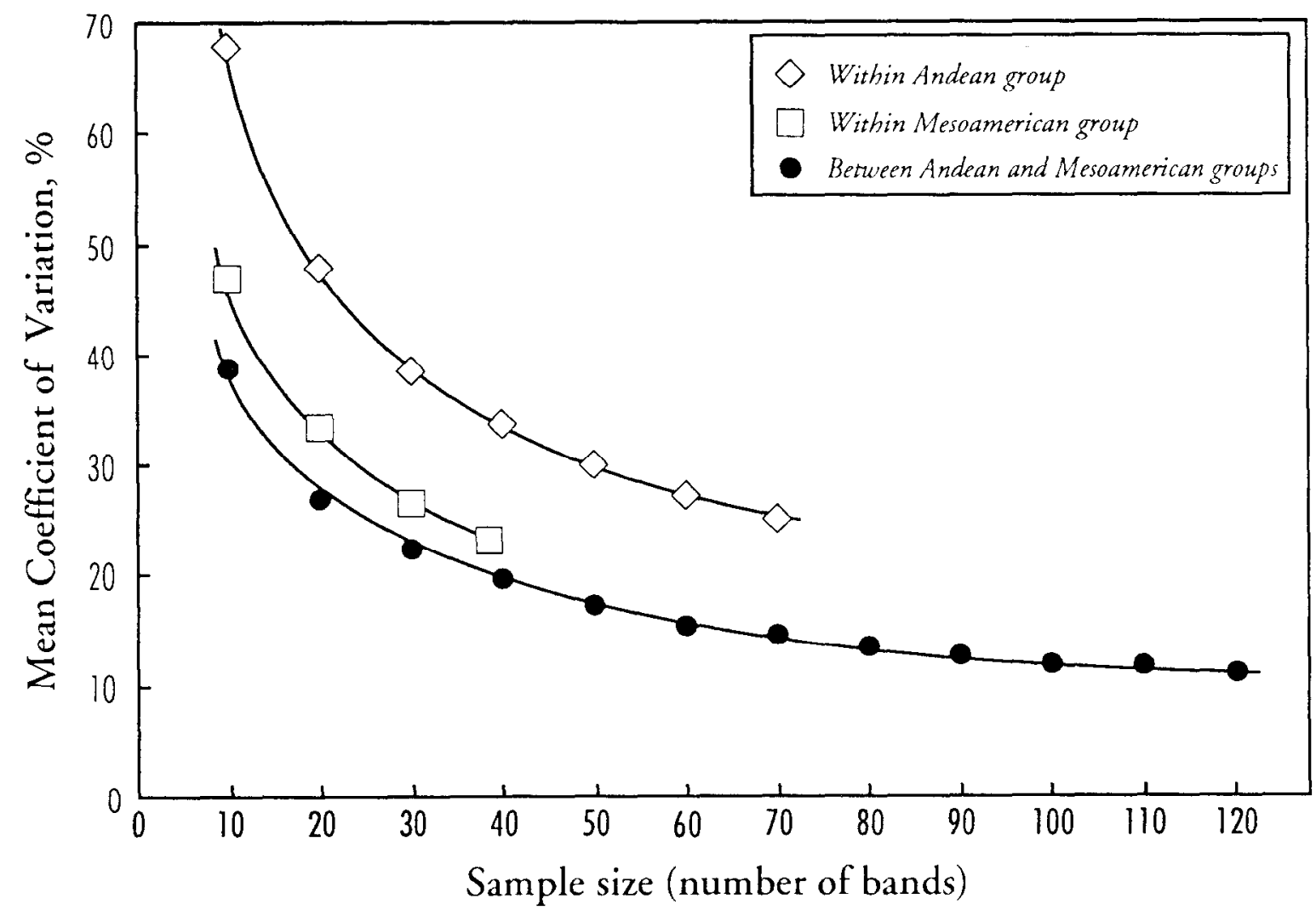

Fig. 3. Sampling variance of genetic distance displayed as a plot of the coefficient of various vs. simple size within and between lima bean acceessions corresponding to the Andean and Mesoamerican gene pools.

Table 3. RAPD marker diversity and $r$ tests of differences among Andean, Mesoamerican, and Fordhook groups of Phaseolus lunatus.

\begin{tabular}{|c|c|c|c|c|c|}
\hline \multirow[b]{2}{*}{ Group } & \multirow{2}{*}{$\begin{array}{l}\text { No. of } \\
\text { individuals }\end{array}$} & \multirow{2}{*}{$\begin{array}{c}\text { RAPD marker } \\
\text { diversity }\end{array}$} & \multicolumn{3}{|c|}{ t Tests } \\
\hline & & & Mesoamerican & Andean & Fordhook \\
\hline Mesoamerican & 35 & $0 . \overline{110}$ & $\overline{-\cdots}-\overline{-}$ & $1.000^{2}$ & 2.96 \\
\hline Andean & 25 & 0.097 & $1.00^{45}$ & -.. & 2.42 \\
\hline Fordhook & 5 & 0.062 & $2.96^{\circ}$ & 2.42 & -- \\
\hline
\end{tabular}

${ }^{\bar{z}}$ Accessions that correspond to Mesoamerican and Andean gene pools and the Fordhook group that are cultivars or landraces phenotypically similar to the culitvar Fordhook.

'RAPD marker diversity is the mean over 125 RAPD loci scored for Nei's gene diversity at a locus (2pqn) (kn -1$]$, where $n=$ number of individuals, and $\mathrm{p}$ and $\mathrm{q}=$ the frequency of presence or absence of a band, respectively.

NS, $* *$ Nonsignificant or significant ar $P=0.01$. 
of the exotic accessions included in this study precluded organization based on yield and quality characteristics (Hartmann, 1969). To evaluate the breeding value of unadapted lima bean accessions will first require the development of populations and selection for adaptation. Knowledge of the organization of these lima bean accessions permits prudent investment of time and resources in the choice of fewer, more-diverse parents to cross in the development of populations for selection for adaptation.

Knowledge of genetic relationships when complemented by phenotypic data can reveal sources of desirable characteristics in more closely related accessions. This combined knowledge may permit the recovery of the recurrent parents' phenotype in fewer backcross generations than would be required for a more-distantly related donor parent. For example, one of the objectives of our lima bean breeding program is the development of larger seed size in Henderson-type cultivars. The two large-seeded accessions that clustered with the otherwise small-seeded types may represent a useful source of genetic variation for increased seed size within the Mesoamerican gene pool.

To maximize genetic variation, populations derived from Mesoamerican $\times$ Andean crosses would be more variable than crosses made within either gene pool. The two gene pools are interfertile; however, crosses between them sometimes produce lethals among $\mathrm{F}_{2}$ segregants (Erickson, 1982). Populations developed from crosses between cultivars in the Mesoamerican gene pool and Fordhook group would also produce greater variation than crosses made within the Mesoamerican gene pool. Moreover, crosses between Henderson and Fordhook types, which are commercial varieties, will likely maintain seed quality and horticultural characteristics.

\section{Literature Cited}

Baudoin, J.P. 1988. Genetic resources, domestication and evolution of lima bean, Phaseolus lunatus , p. 393-407. In: P. Gepts (ed.). Genetic resources of Phaseolus beans. Kluwer Academic Publishers, Dorthrecht, The Netherlands.

Debouck, D. G., A. Maquet, and C.E. Posso. 1989. Biochemical evidence for two different gene pools in lima beans, Phaseolus vulgaris L. Annu. Rpt. Bean Improvement Coop. 32:58-59.

dos Santos, J.B. , J. Nienhuis, P. Skroch, J. Tivang, and M.K. Slocum. 1994. Comparison of RAPD and RFLP genetic markers in determining genetic similarity among Brassica oleracea L. genotypes. Theoretical Applied Genet. 87:909-915.

Dudley, J. W. 1994. Comparison of genetic distance estimators using molecular marker data, p. 3-7. In: Analysis of molecular marker data. Crop Sci. Sot. Amer., Madison, Wis.

Efron, B. and R. Tibshirani. 1986. Bootstrap methods for standard errors, confidence intervals, and other measures of statistical accuracy.

Erickson, H.T. 1982, Lima bean Legacy. HortSciencc 17:702.

Excoffier, L., P.E. Smouse, and J. M. Quattro. 1992. Analysis of molecular variance inferred from metric distances among DNA haplotypes: Application to human mitochondrial DNA restriction data. Genetics
131:479-491.

Goodman, M.M. and C. W. Stuber. 1980. Genetic identification of lines and crosses using isoenzyme electrophoresis. Proc. 35th Annu. Corn, Sorghum Res. Conf. 35:10-31.

Gower, J.C. 1985. Measures of similarity, dissimilarity, and distance, p. 297-405. In: S. Kotz and N.L. Johnson (eds.). Encyclopedia of statistical sciences. vol. 5. Wiley, New York.

Harlan, J.R. and J.M.J. de Wet. 1971. Toward a rational classification of cultivated plants. Taxon 20:509-517.

Hartmann, R.W. 1969. Photoperiod responses of Phaseolus plant introductions in Hawaii. J. Amer. Soc. Hort. Sci. 97:600-603.

Helentjaris, T., M. Slocum, S. Wright, A. Schaefer, and J. Nienhuis. 1986. Construction of genetic linkage maps in maize and tomato using restriction fragment length polymorphisms. Theoretical Applied Genet. 72:761-769.

Holland. A. H., W.H. Lange, J.B. Kendrick, and J.H. MacGillivray. 1953. Production of lima beans for freezing. Univ. of California, Berkeley, Ext. Serv. Circ. 430.

Mackie, W.W. 1943. Origin, dispersal, and variability of the lima bean, Phaseolus lunatus. Hilgardia 15:1-29.

Maquet, A., A. Gutierrez, and D.G. Debouck. 1990. Further biochemical evidence for the existence of two gene pools in lima beans. Annu. Rpt. Bean Improvement Coop. 33: 128-I 29.

Maquet, A., B. Wathelet, and J.P. Boudoin. 1993. Further studies on the genetic diversity of lima beans (Phaseolus vulgaris L.) using allozymes. Annu. Rpt. Bean Improvement Coop. 36:55-56.

Nei, M. 1987. Molecular evolutionary genetics. Columbia Univ. Press, New York.

Pollard. L.H. and A.R. Hamson. 1970. Kingston-A new lima bean variety. Utah Sci, 31:3.

Rogers, S.O. and A.J. Bendich. 1988. Extration of DNA from plant tissues. Plant molecular biology manual A6:1-10. Kluwer Academic Publishers, Dordrecht, The Netherlands.

Skroch, P., J. Tivang, and J. Nienhuis. 1992. Analysis of genetic relationships using RAPD marker data, p. 26-30. In: Applications of RAPD technology to plant breeding. Crop Sci. Soc. Amer., Madison, Wis.

Smith O. S., J.S.C. Smith, S.L. Bowen, R.A. Tenborg, and S.J. Wall. 1990. Similarities among a group of elite maize inbreds as measured by peidgree. $F_{1}$ groin yield, grain yield, heterosis and RFLPs. Theoretical Applied Genet. 80:833-840.

Soiler, M. and J.S. Beckmann. 1983. Genetic polymorphism in varietal identification and genetic improvement. Theoretical Applied Genet. 67:25-33.

Tivang, J., J. Nienhuis, and O.S. Smith. 1994. Sampling variances of molecular marker data sets using the bootstrap. Theoretical Applied Genet. (In press.)

Weeden, N. F.. G.M. Timmerman, M. Hemmat, B.E. Kneen, and M.A. Lodhi, 1992. Inheritance and reliability of RAPD markers. p. 12-17. In: Applications of RAPD technology to plant breeding. Crop Sci. Soc. Amer.. Madison, Wis.

Welsh, J. and M. McClelland. 1990. Fingerprinting genomes using PCR with arbitrary primers. Nucleic Acids Research. 18:7213-7218.

Wilkinson, L. 1989. SYSTAT: The system for statistics. SYSTAT, Evanston, Il.

Williams, J. G. K., A.R. Kubelik, K.J. Livak, J.A. Rafalski, and S.V. Tingey. 1990. DNA polymorphisms amplified by arbitrary primers are useful as genetic markers. Nucleic Acids Res. 18:6531-6535. 